\title{
Constraints to consumption of South Africa's national parks among the emerging domestic tourism market
}

\author{
Elizabeth A Kruger ${ }^{a}$ \& Anneli Douglas ${ }^{b}$ \\ ${ }^{a}$ Lecturer, Division Tourism Management, University of Pretoria, EMS Building, Pretoria 0002, South Africa \\ ${ }^{b}$ Senior lecturer, Division Tourism Management, University of Pretoria, EMS Building, Pretoria 0002, South \\ Africa
}

Tourism plays a recognised role in the South African economy, even though it is faced with a number of challenges including levels of seasonality, geographic spread and differing levels of travel and tourism culture within population groups. Literature speaks to the role that domestic tourism can play in addressing these challenges. Within the South African context, emerging markets are population groups entering the market in increasing numbers as domestic tourists, especially those previously neglected during the years of segregation through apartheid. The focus of this exploratory study was to identify the constraints that deter the South African emerging black domestic market from visiting national parks, and more specifically the Kruger National Park. A survey of 350 individuals support existing literature, but highlight the importance of time, distance and affordability as constraints to this market. The study identifies areas in which products could be adapted, as well as aspects that could be considered when formulating marketing messages aimed at this market.

Keywords: domestic tourism; emerging black market; constraints; national parks

\section{Introduction}

During the recent global financial crisis, the tourism industry's direct contribution to worldwide gross domestic product (GDP) dropped from 3.08\% in 2007 to around $2.86 \%$ at the lowest points in 2010 and 2011. Making a relatively fast recovery however of $3.1 \%$ in 2013 and with a predicted growth of up to $4.4 \%$ in 2023, the industry once again demonstrated its resilience (WTTC, 2013). Amidst this volatility, destinations worldwide are increasingly turning toward domestic tourism as contributor to a sustained tourism economy (Smeral, 2010). It is stated that a vibrant domestic tourism sector can "cushion the industry from fluctuations of the international tourism market and bring stability and predictability in the industry" (Okello et al, 2012:79). Domestic spending makes up the largest part of worldwide travel spend $(70.7 \%$ in 2012$)$ and also has a slightly larger 
expected growth at 4.6\% in 2023 (WTTC, 2013). The continued growth in domestic tourism is linked to the trend for shorter holidays closer to home, a phenomenon referred to as 'staycation' (Papatheodorou et al., 2010) and global trends indicate that tourism is becoming a regional/national rather than a global phenomenon (NDT, 2011a).

Domestic tourism remains an under-researched theme in developing countries partly due to the difficulty to track domestic tourism and with governments and policy makers placing emphasis on the attractive higher expenditures of foreign visitors (Alipour et al., 2013; Bui \& Jolliffe, 2011; Ghimire, 2013; Sun et al., 2013). Both the benefits and problems of emerging mass domestic tourism have been largely ignored by policy makers in developing countries, despite the increased importance of this market to these economies (Alipour et al., 2013; Hampton \& Jeyacheya, 2014). Even in countries where the number of domestic travellers exceeds that of international travellers, domestic tourism development takes place without any systematic government planning (Ghimire, 2013). South Africa represents one of the few examples of a developing country where the national government has made domestic tourism an explicit priority (Rogerson \& Lisa, 2005). The National Department of Tourism (NDT) has identified increasing domestic tourism's contribution as a percentage of the overall tourism contribution to GDP from $54.8 \%$ in 2009 to $60 \%$ by 2020 . Strategies to achieve this include increasing domestic tourism expenditure, tourist volumes and enhancing a travel culture among South Africans (NDT, 2011b). The emerging black ${ }^{1}$ domestic market for leisure tourism presents a distinct opportunity to achieve these objectives, given the significant growth potential in terms of size and spending power displayed by this market segment (NDT, 2011a; Visagie \& Posel, 2013). Despite promotional efforts which started some 20 years ago (Rogerson \& Lisa, 2005), domestic trips have shown a decline and a call has been made to the industry to respond with product offerings that appeal to members across all market segments (NDT, 2011a). Such initiatives will arguably fail without sufficient market knowledge, as is the case in most developing markets (Ghimire, 2013).

An increasing number of studies are aimed at understanding the factors that drive domestic tourism in less developed countries. Examples include the study of destination loyalty (Sun et al., 2013) and the effect of income (Yang et al., 2014) among Chinese;

\footnotetext{
${ }^{1}$ Generic term which means Africans, Coloureds and Indians (NDT, 2011a). Note that no distinction is made between the various ethnic groups that exist within the black African population group.
} 
destination choice factors among Kenyans (Mutinda \& Mayaka, 2012); travel motivations among Vietnamese (Bui \& Jolliffe, 2011); intrapersonal constraints among Indian travellers (Anil et al., 2010); and the experiences of Israelis being tourists in their home country (Singh \& Krakover, 2015).This study therefor aimed to contribute to knowledge of a domestic market in a developing country by exploring the travel motivations and constraints to domestic travel experienced by the emerging black domestic tourism market in South Africa. As point of reference, the Kruger National Park is used as an attraction that has held enduring popularity among members of the traditional South African domestic market (Grundlingh, 2006).

\section{Domestic tourism in South Africa}

\subsection{Overview of development and strategies}

Tourism has been greatly affected by the policy of apartheid (Mkhize, 1994) and asthe domestic tourism market was traditionally dominated by a white population who had the greatest levels of wealth, mobility and access to amenities (Flutter \& Wood, 1997; Koch \& Massyn, 2013) the industry mostly catering to serve this white minority (Rogerson \& Lisa, 2005). Only a few domestic destinations catered for black South Africans, but the facilities were limited and often poor in quality (Grundlingh, 2006; Mkhize, 1994; Rogerson \& Lisa, 2005). Since the birth of democracy in South Africa in 1994, a dramatic change in the composition and nature of domestic tourism has been witnessed. Given the poor perception of the widening leisure interests of the emerging market, the industry has however been accused of insufficient planning, leaving the black population with limited recreational and leisure activities that do not accommodate their needs (Ferrario, 1988; NDT, 2011a). Still, much has been done to increase awareness of travel among members of this market through various promotional channels (Lisa, 2004 in Rogerson \& Lisa, 2005).

In 2004 the national Department of Environmental Affairs and Tourism (DEAT) launched the country's first national domestic tourism growth strategy; with a clear priority on expanding black domestic tourism. The strategy was supported by a marketing campaign run by South African Tourism, called 'Sho't Left', aimed at spreading the message that there were many affordable travel options available in close proximity (Rogerson \& Lisa, 2005; NDT, 2011a). This was followed by the newly established NDT's Domestic Tourism 
Branch and Domestic Tourism Growth Strategy (DTGS), supported by a new consumer campaign "Whatever you are looking for, it is here". The new DTGS includes prioritised campaigns aimed at both the lower and higher ends of the market, to create a holiday culture among previously disadvantaged groups, and to extend VFR visits into leisure tourism (NDT, 2011a). Five target markets were identified in the Marketing Growth Strategy of 2011 - 2013 (SAT, 2010) and the DTGS (which stretches until 2020), consisting of one segment exclusively focusing on the black African population ('Well-to-do Mzanzi Families') and two more focusing on the black, coloured and Indian population ('New Horizon Families' and 'High Life Enthusiasts'). . Strategic actions to increase tourism volume include creating a domestic travel card similar to SANParks' Wild Card and packaging linked experiences across the country, for example National Parks Footprint, in partnership with the industry (NDT, 2011a).

\subsection{Current domestic market profile}

By 2011 only $44 \%$ of the total South African adult population was said to be participating in domestic travel, though this number has been showing improvement (NDT, 2011a). Although VFR remained the major purpose of domestic travel, the share thereof decreased by $5 \%$ from $77 \%$ to $72 \%$ in the period July to September 2013 compared to the same period in 2012. The biggest inhibiting factors have been identified as the perception that travel is not affordable and that people have no reason to take a trip (NDT, 2011a; SAT, 2013).

\subsection{The emerging black domestic tourism market}

Within the South African context, emerging markets are population groups entering the market in increasing numbers as domestic tourists, especially those previously neglected (DEAT, 1996). Gradual improvement in the socio-economic position of the black population in the country has led to an expected growth of this segment to become a greater part of the domestic tourism market. This trend fits in with a global trend across many developing countries where leisure travel is no longer the exclusive privilege of the upper classes, but where growth is extending beyond the growing middle class to include members of the lower middle class participating in leisure travel (Rogerson, 2004).

As an outcome of government initiatives taken after apartheid, there has been a growth of a substantial black middle class (Donaldson et al., 2013; Rogerson \& Lisa, 2005; Visagie \& 
Posel, 2013). Recent analyses of the 'affluent households' by racial group disclosed major shifts in the composition of the affluent in South Africa; unfortunately mostly being in an unequal manner even within racial groups (Leibbrandt et al., 2012; Tregenna \& Tsela, 2012). Visagie and Posel (2013) define the African middle class as African households which received a total household income in excess of R12 000 a month and fall into the LSM 9 and 10 group. Within a timespan of eight years (2004 to 2012), the middle class in South Africa rose from 1.6 to 4.2 million adults. Of these 4.2 million adults, $51 \%$ were black, 34\% white, 9\% coloured and 6\% Indian; representing a dramatic shift from the 2004 proportions in the first two categories: $52 \%$ white, $32 \%$ black, $10 \%$ coloured and $6 \%$ Indian (Visagie \& Posel, 2013). In the Income and Expenditure Survey (IES) 2010/2011, black households showed a $34.5 \%$ income increase over one year (StatsSA, 2012). Despite this growth, very little research has been focused on the ethnocentric tendencies and buying behaviour of the emerging black middle class as a consumer market (Goldberg \& Jansen van Rensburg, 2013). With a duality of social identities emerging within this market, also known as the 'black diamonds', much remains to be researched (Donaldson et al., 2013).Similarly, little research has been done to tap into the emerging black middle class as a tourist market; with research in this field being fragmented and lacking cohesion from the researchers (NDT, 2011a). While some research has been conducted on the domestic tourism market in South Africa (Ferrario, 1988; Flutter \& Wood, 1997; Grundlingh, 2006; Koch \& Massyn, 2013; Mkhize, 1994; Rogerson \& Lisa, 2005; Rule et al. 2004; Saayman et al., 2001; Visser, 2004), little remains known about the motivations, needs and preferences of this market. There seemingly remains the tendency to travel for the purpose of visiting friends and relatives (VFR) (Rule et al., 2003; SAT, 2013), despite campaigns to encourage holiday travel that is associated with higher levels of spending (NDT, 2011a; Rogerson \& Lisa, 2005).

\section{Visitor markets of the Kruger National Park}

By 2013 the number of black visitors (referred to as 'Black guests') to all South African National Parks increased by $11,4 \%$ from 389624 to 434216 , making up $25.5 \%$ of total South African guests to the Park (in increase of 1.9\%). This included an increase of $10.5 \%$ for day visitors and an increase of $19.4 \%$ for overnight guests. The increase in the emerging market is in line with the organisational goals of SANParks to encourage all South Africans to consider the country's national parks as possible holiday destinations (Van der Merwe \& Saayman, 2008). 
The world-renowned Kruger National Park is South Africa's jewel and is world famous because of its wildlife. Its official proclamation in 1926 is said to have spurred leisure tourists to include visits to South Africa's wildlife attractions (Rogerson \& Lisa, 2005) and it has held enduring popularity among members of the traditional domestic market (Grundlingh, 2006). As a key nature-based attraction in South Africa, the total number of visitors amounted to 1450481 over the period extending from March 2012 to March 2013; along with 913237 bed nights sold at an occupancy rate of $77.7 \%$. The Park accounts for $66.9 \%$ of all SANParks activities (SANParks, 2013).

\section{Constraints to consume tourism products}

\subsection{Constraints to leisure travel}

The study of tourist motivations is well established in the literature (Pearce, 2011). As tourists will often have more than one motivation to travel, the lists of tourist motivations are extensive and often present a combination of simultaneous motives (Pearce \& Lee, 2005)..It has been stated that the main purpose of trip for domestic travel include pilgrimages, VFR, business travel, and increasingly a segment of leisure travel (Rogerson, 2004).Intrinsic motivations may include relaxation, family togetherness, escapism and achievement (Bui \& Jolliffe, 2011; Özel \& Kozak, 2012); similar to that of international travel in many instances.

As the opposite to travel motivations, constraints have been defined as factors that limit the formation of leisure preferences and that inhibit or prohibit participation and enjoyment in leisure, often resulting in non-participation (Crawford \& Godbey, 1987; Jackson, 1991). The popular Hierarchical Model of Leisure Constraints order constraints into three categories: intrapersonal, interpersonal and structural constraints (Crawford et al., 1991) whereleisure preferences are formed following the negotiation or absence of the various constraints (Gilbert \& Hudson, 2000). Intrapersonal constraints are defined as individual psychological qualities that affect the development of leisure preferences; including stress, fear, shyness, depression, anxiety, reference group attitudes, perceived self-skill, and perceived appropriateness of various leisure activities (Crawford et al., 1991). Interpersonal constraints are defined as social factors appearing within social exchanges and interactions and occur as a result of interaction or the relationship between individuals' characteristics (Nyaupane et al., 2004); including lack of interest of partners or friends to 
participate within the tourism product offering (Gilbert \& Hudson, 2000; Thapa, 2012). Structural constraints are associated with the setting and are externally derived, including financial resources, time, access, availability of opportunity, family life cycle, season, work schedule and climate (Crawford \& Godbey, 1987). The three stages in the model are hierarchical as intrapersonal constraints are encountered first, followed by interpersonal and eventually structural constraints; or where structural constraints are followed by the negotiation of the first two types of constraints (Crawford et al., 1991). Even though the individual may negotiate around structural constraints, some of these constrains may prove to be insurmountable (Hinch \& Higham, 2011). This process of negotiation is increasingly receiving attention in constraints literature to move beyond measuring the mere perceptions of constraints, but rather exploring deeper rooted factors that contribute to the formation of such perceptions (Godbey et al., 2010).

Jackson (1993) also identified six dimensions of constraints that appear to be common across settings: (a) social isolation: characteristics that involve interaction between people; (b) accessibility: lack of or limited access to transportation; (c) personal reasons: representing an individual's abilities or motivations; (d) cost: experience costs or the cost of equipment; (e) time: referring to levels and intensity of participation; and (f) facility: crowding and maintenance. Several researchers have explored constraints within the tourism context. Hung and Petrick (2012) tested the Motivation-Opportunity-Ability (MOA) model to explain travel intentions; highlighting the importance of constraint negotiation. Some of the constraints that can be associated with the tourism industry, and that can affect the consumption of its product offerings, include lack of money, insufficient time, inaccessibility, and unsuitable weather conditions (Thapa, 2012).

In the South African context, constraints to domestic travel have been identified as "cannot afford to travel", "no reason to take a trip", "time constraints", no income/unemployment" and a "dislike of travelling" (NDT, 2011a). According to the Hierarchical Model, these would be categorised as intrapersonal (no reason; dislike) and structural (too expensive; time; no income). A study conducted by Sindiga (1996) similarly found structural constraints (wages being too low to afford tourism) to be a major constraint for Kenyans to travel domestically; requiring adjustments leading to tourism product diversification and spatial deconcentration of facilities to cater for a broader cross-section of people. At the same time, research has indicated increased countering of constraints to domestic tourism 
in developing countries through increased capacity and desire to travel among urban populations, improvements in economies and living standards, developments in transport, and tailored marketing to address market preferences (discussed in Rogerson \& Lisa, 2005).

\subsection{Constraints to visiting national parks}

Despite the growing popularity of nature-based tourism (Wight, 2002; Teigland, 2000), it has been found that individuals perceive constraints to participation in nature-based tourism comparable to that of traditional leisure activities. In a study based on the Hierarchical Model of Constraints, Pennington-Gray and Kerstetter (2002) found structural constraints such as time and money to be most important, followed by interpersonal constraints such as the influence of friends, and lastly intrapersonal constraints. A similar study (Pennington-Gray et al.,2002) also identified various constraints at these three levels: intrapersonal (lack of interest, fear of crime, uncertainty about having the required skills to participate); interpersonal (lack of interest from companion(s) and other family members); and structural (lack of time/money/information/transportation/equipment, poor weather conditions, parks being too crowded/too far away, and facilities not being well maintained).

The dominance of structural constraints has similarly been noted by other researchers. Despite the attractiveness of wildlife and natural amenities, a lack of quality infrastructure places a serious limitation on visitations to parks by both domestic and international visitors (World Bank, 2007). A study on the Kafue National Park in Zambia (Thapa, 2012) found that international and domestic visitor segments indicated varying degrees of perceived constraints, with structural constraints being more common among domestic visitors. In a study on factors influencing the surrounding domestic population to visit Nairobi National Park in Kenya (Okello et al., 2012), it was found that majority (66\%) of the community had visited the park. Even though the lack of free time (structural), lack of interest in wildlife (personal), or the thinking that protected areas in Kenya were meant for foreign tourists (personal), were not hindrances to local community visiting the parks, they noted that key constraints were lack of extra disposable income (structural), high cost of food and hospitality services inside the park for local communities (structural), and poor marketing of parks especially targeting local Kenyans (structural). Schneider et al. (2011) also found structural constraints to be dominant among visitors to wilderness areas. 
Despite the evident dominance of structural constraints, all of the constraints contribute to the way individuals perceive participation in nature-based tourism, and they can be broadly applicable to parks throughout the world in varied degrees.

\section{Methodology}

A quantitative methodology was used for this exploratory study. Data was collected from members of the target population at a shopping mall situated $426 \mathrm{~km}$ from Kruger National Park in Mpumalanga province.. Mpumalanga province is home to a large section of Kruger National Park and is also the second largest visitor generating province for domestic visitors to all SANParks (SANParks, 2013). Non-probability (convenience) sampling in the form of a mall-intercept survey was utilised. The target population consisted of black ${ }^{2}$ adults (aged 18 years or older) who had never visited the Kruger National Park. A selfadministered questionnaire consisting of ten questions was used. Questions 1 and 2 were qualifying questions (respondent age and previous visitation to Kruger National Park). Question 3 enquired about the last destination visited in South Africa. If none, respondents listed multiple reasons why they had not been able to go on holiday (based on the constraints identified in the literature). Questions 5 and 6 focused on multiple reasons why the respondent would or would not visit the Kruger National Park (based on the constraints identified in the literature). Question 7 asked respondents to indicate the importance of a list of destination features on a 5 -point Likert scale $(1=$ not at all important; $5=$ very important). Questions 9 and 10 captured demographic details of respondents.

\section{Results}

\subsection{Descriptive statistics}

A total of 350 usable questionnaires were collected. Both genders were almost equally represented in the sample. The majority of the respondents were of the age groups 18-25 years and $26-35$ years (28.9\% each). The dominant income categories were R10 000R19 999 (35.1\%) and R5 000-R9 999 (34.3\%). The demographic profiles of the respondents are further illustrated in Table 1.

\footnotetext{
${ }^{2}$ Generic term which means Africans, Coloureds and Indians (NDT, 2011a).
} 
Table 1: Demographic profile of respondents

\begin{tabular}{|l|c|c|c|}
\hline Variable & Category & Frequency (n) & Percentage (\%) \\
\hline \multirow{3}{*}{ Gender } & Male & 176 & 50.3 \\
& Female & 174 & 49.7 \\
& Total & 350 & 100 \\
\hline \multirow{5}{*}{ Age } & $18-25$ & 101 & 28.9 \\
& $26-35$ & 101 & 28.9 \\
& $36-45$ & 68 & 19.4 \\
& $46-55$ & 63 & 18 \\
& $56-65$ & 14 & 4 \\
& $65+$ & 3 & 0.9 \\
& Total & 350 & 100 \\
\hline \multirow{5}{*}{ Income } & Less than R5 000 & 55 & 15.7 \\
& R5 000-R9 999 & 120 & 34.3 \\
& R10 000-R19 999 & 123 & 35.1 \\
& R20 000-R30 000 & 31 & 8.9 \\
& More than R30 000 & 21 & 6 \\
& Total & 350 & 100 \\
\hline
\end{tabular}

Respondents were asked how often they go on holiday; with the majority selecting "Seldom" (41.4\%), followed by "Regularly" (26.3\%). A quarter of respondents selected "Never" (25.4\%). The respondents that answered "Often", "Regularly" and "Seldom" were asked to write down the last holiday destination that they had visited in South Africa. The most visited province was Kwa-Zulu Natal (52.9\%), followed by the Western Cape (17.6\%) and then the North-West (17.6\%). Kwa-Zulu Natal included destinations such as Durban, Umhlanga, Ballito and Margate. Western Cape destinations were mostly Cape Town; North-West was Sun City; Eastern Cape was either Port Elizabeth or East London; Limpopo included Phalaborwa and Bela-Bela; Free State included the Vaal Dam (largest stretch of shoreline situated in this province); Northern Cape included Kgalagadi Transfrontier Park; and lastly, Gauteng included Soweto.

The 89 respondents that answered "Never" in the previous question on travel frequency answered a multiple choice question about the reasons why they have not been able to go on holiday (refer to Table 2). The main reason identified by respondents $(68.5 \%)$ was that they can't afford it. Table 2 also indicates the type of constraints mentioned based on the Hierarchical Model of Constraints. Interestingly, in terms of general 'holiday' experiences, intrapersonal constraints related to feelings of uncertainty, disinterest and lack of skills featured strongly. 
Table 2: Reasons for not going on holiday

\begin{tabular}{|l|c|c|}
\hline Reasons & $\begin{array}{c}\text { Frequency } \\
\text { (n) }\end{array}$ & $\begin{array}{c}\text { Type of } \\
\text { constraint }\end{array}$ \\
\hline Can't afford it & 61 & Structural \\
Enjoy the comfort of home & 17 & Intrapersonal \\
Don't know where to go & 15 & Intrapersonal \\
Too much planning & 14 & Intrapersonal \\
Holiday destinations are too far & 11 & Structural \\
Not interested in travelling & 8 & Intrapersonal \\
\hline
\end{tabular}

All the respondents then had to indicate the possible main reasons for visiting the Kruger National Park, should they consider it (Table 3). The top three reasons selected included a relaxing atmosphere (44.9\%), an interest in wildlife (43.4\%) and liking outdoor activities $(28.9 \%)$.

Table 3: Reasons for considering visiting Kruger National Park

\begin{tabular}{|l|c|}
\hline Reasons & $\begin{array}{c}\text { Frequency } \\
\text { (n) }\end{array}$ \\
\hline Relaxing atmosphere & 157 \\
Interest in wildlife & 152 \\
Like outdoor activities & 101 \\
I would not consider it & 47 \\
Affordable family holiday & 43 \\
Close holiday destination & 40 \\
\hline
\end{tabular}

Respondents were then asked to indicate all the reason(s) why they have never visited the Kruger National Park (could choose more than one option) (Table 4). The top three reasons included that it was too expensive (47\%), they didn't have enough time to visit $(31 \%)$ and that it was too far to travel to (23\%). Table 6 illustrates the frequencies for all the reasons as well as the type of constraint mentioned based on the Hierarchical Model of Constraints. From the table it is clear that, similarly to what has been found in the literature, structural constraints feature strongly as deterrents to visiting the Park.

Table 4: $\quad$ Reasons for not visiting Kruger National Park

\begin{tabular}{|l|c|c|}
\hline Reasons & $\begin{array}{c}\text { Frequency } \\
\text { (n) }\end{array}$ & $\begin{array}{c}\text { Type of } \\
\text { constraint }\end{array}$ \\
\hline It is too expensive & 166 & Structural \\
I don't have enough time to visit & 107 & Structural \\
It is too far to travel to & 80 & Structural \\
Family/friends are not interested & 76 & Interpersonal \\
Unsure about availability of suitable accommodation & 68 & Structural \\
Lack of information available about the park & 58 & Structural \\
I am not interested in wildlife & 50 & Intrapersonal \\
I do not like outdoor activities & 30 & Intrapersonal \\
It is not an appealing atmosphere & 17 & Structural \\
Weather conditions are unsuitable & 13 & Structural \\
It is not a family holiday destination & 9 & Interpersonal \\
\hline
\end{tabular}


Respondents had to rate a list of features according to their importance when considering going on holiday to a destination such as the Kruger National Park. This list was divided into four sections: infrastructure, nature, activities and general features (refer to Table 5).

The most important infrastructural features were indicated as quality of the buildings $(m=4.21)$ and ease of accessibility $(m=4.04)$. There was least agreement among respondents on the importance of affordable shopping facilities $(S D=1.175)$. A clean and unpolluted environment $(m=4.31)$ and beautiful natural scenery and landscape $(m=4.14)$ were the two most important natural features. There was least agreement among respondents on the importance of various species and wildlife (SD=1.153). The three most important features concerning activities included something to do for the whole family ( $m=3.87$ ), having different experiences $(m=3.79)$ and a variety of social activities ( $m=3.64)$. There was least agreement among respondents on the importance of various activities for children $(S D=1.253)$. The last section concerning the general features of a destination such as Kruger National Park indicated safety and security as the most important factor $(m=4.56)$, closely followed by value for money $(m=4.51)$ and welcoming and knowledgeable staff $(m=4.29)$. There was least agreement among respondents on the importance of the levels of overcrowding ( $S D=0.987)$.

Table 5: Importance of various categories of features

\begin{tabular}{|c|c|c|}
\hline Features & Mean & Std.dev \\
\hline Infrastructure & 3.93 & 1.000 \\
\hline Quality of the buildings & 4.21 & .929 \\
\hline Easily accessible & 4.04 & .854 \\
\hline Decent roads & 3.93 & 1.027 \\
\hline Good restaurants & 3.90 & 1.002 \\
\hline Various and varied accommodation options & 3.89 & 1.000 \\
\hline Affordable shopping facilities & 3.63 & 1.175 \\
\hline Natural & 4.06 & 0.950 \\
\hline Clean and unpolluted environment & 4.34 & .783 \\
\hline Beautiful natural scenery and landscape & 4.14 & 841 \\
\hline Various species of wildlife & 3.92 & 1.153 \\
\hline Suitable weather conditions & 3.85 & 1.006 \\
\hline Activities & 3.59 & 1.110 \\
\hline Something to do for the whole family & 3.87 & 1.108 \\
\hline Having different experiences & 3.79 & .974 \\
\hline Variety of social activities & 3.64 & 1.055 \\
\hline Rich cultural heritage & 3.59 & 1.098 \\
\hline A lot of outdoor activities (adventure/ sport) & 3.53 & 1.167 \\
\hline Limited activities to ensure a relaxed atmosphere & 3.48 & 1.043 \\
\hline Educational activities & 3.41 & 1.190 \\
\hline Various activities for children & 3.39 & 1.253 \\
\hline General features & 4.24 & 0.850 \\
\hline Safe and secure destination & 4.56 & .711 \\
\hline Value for money & 4.51 & 741 \\
\hline
\end{tabular}


Welcoming and knowledgeable staff

Easy to find information

Various booking options

Rules and regulations to manage visitors

Level of overcrowding

\begin{tabular}{l|l}
4.29 & .820 \\
4.19 & .835 \\
4.09 & .920 \\
4.03 & .922 \\
3.99 & .987
\end{tabular}

Table 6 indicates the top ten most important features across all categories.

Table 6: Top ten most important features

\begin{tabular}{|l|c|c|c|}
\hline Feature & Mean & Std.dev & Category \\
\hline Safe and secure destination & 4.56 & .711 & General \\
\hline Value for money & 4.51 & .741 & General \\
\hline Clean and unpolluted environment & 4.34 & .783 & Natural \\
\hline Welcoming and knowledgeable staff & 4.29 & .820 & General \\
\hline Quality of the buildings & 4.21 & .929 & Infrastructure \\
\hline Easy to find information & 4.19 & .835 & General \\
\hline Beautiful natural scenery and landscape & 4.14 & .841 & Natural \\
\hline Various booking options & 4.09 & .920 & General \\
\hline Easily accessible & 4.04 & .854 & Infrastructure \\
\hline Rules and regulations to manage visitors & 4.03 & .922 & General \\
\hline
\end{tabular}

The respondents were then asked to indicate the different types of travel information sources used when travelling to a destination (Table 7). The top three information sources used by the respondents included friends and relatives $(59.4 \%)$, search engines $(52.9 \%)$ and brochures (42.6\%).

Table 7: Sources of information

\begin{tabular}{|l|c|}
\hline Information sources & $\begin{array}{c}\text { Frequency } \\
\text { (n) }\end{array}$ \\
\hline Friends and relatives & 208 \\
Search engines (e.g. Google) & 185 \\
Brochures & 149 \\
Television/radio advertisements & 127 \\
Travel magazines & 115 \\
The official tourism website & 99 \\
Social network (Facebook, Twitter etc.) & 76 \\
Travel agents & 56 \\
Travel blogs & 37 \\
\hline
\end{tabular}

\subsection{Cross tabulations}

Cross tabulations were conducted to determine the level of importance of the various features (indicated in Table 5) in relation to the constraints (indicated in Table 4) The Kolmogorov-Smirnov test indicated non-normality of the data $(p<, 00)$ and resultantly Pearson's Chi-square was used to test the significance of the relationships (95\% 
confidence interval) (refer to Table 8 for the cross tabulations) ${ }^{3}$. Several of the relationships were found to be significant. The majority of respondents who indicated not being interested in wildlife as a constraint indicated the importance of beautiful natural scenery and landscape (77\%), having different experiences (72\%) and something to do for the whole family $(65 \%)$. Respondents who indicated the travel distance as a constraint also indicated the importance of other structural features such as ease to find information (92\%), easy accessibility (90\%) and the quality of the buildings (90\%). Respondents that indicated the Park as being too expensive also placed emphasis on various and varied accommodation options as well as good restaurants (both $81 \%$ ). Respondents that indicated time as a constraint indicated the importance of having different experiences (89\%). Respondents that indicated they don't like outdoor activities, indicated something to do for the whole family as important (72\%), but various species of wildlife not $(70 \%)$. Respondents that indicated lack of information as a constraint also indicated the importance of lot of outdoor (89\%) and educational (87\%) activities. Lastly, respondents that indicated the Park as not having an appealing atmosphere, emphasised the importance of having different experiences (67\%) and a lot of outdoor activities (67\%).

\footnotetext{
${ }^{3}$ The categories 'very important' and 'important' were recoded into one category 'important, while the categories 'not at all important' and 'less important' were recoded into one category 'not important'
} 
Table 8: Cross tabulations of constraints and important features

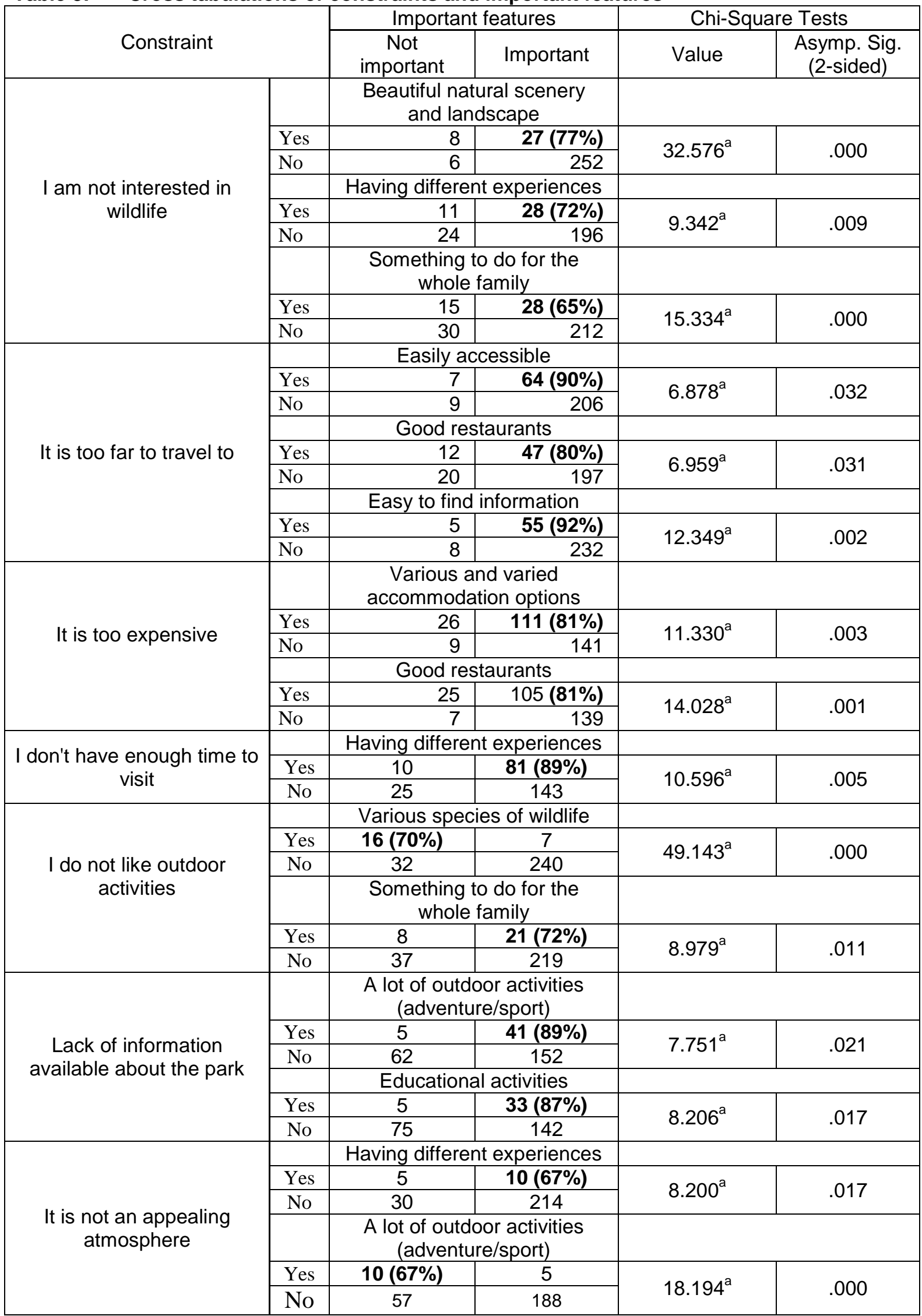




\section{Discussion and conclusion}

This paper aimed to explore some of the constraints keeping members of the emerging black domestic tourism market from visiting Kruger National Park as a leisure destination. From the results, it was found that the majority of respondents went on holiday very seldom and a significant number did not go on holiday at all. The top three reasons indicated by the respondents for not undertaking travel were 'cannot afford it', 'enjoying the comfort of home' and 'not knowing where to go'. The latter two reasons can be classified as intrapersonal constraints and coincide with current statements that there is not a culture of travel among this market (NDT, 2011a). The first reason of affordability is also in line with current market research (SAT, 2013). Majority of respondents that did go on holiday identified KwaZulu-Natal as their last visited destination - coinciding with current market knowledge (SAT, 2013).

The major constraints for not visiting the Kruger National Park were identified as three structural constraints namely finances ('too expensive'), time ('don't have time to visit'), and accessibility ('too far'). One interpersonal constraint ('family/friends not interested') followed, before two more structural constraints that both relate to the availability of information, featured. Where an interpersonal constraint such as disinterest from reference groups is difficult to manage (Thapa, 2012), the other structural constraints are aspects that can be managed through effective communication messages to educate the market and ensure the use of appropriate communication channels. The top sources of information were indicated as friends and family (word of mouth), search engines, brochures, television and travel magazines. Except for search engines, these channels are considered as more 'traditional', with the market shying away from other recently emerging channels such as social media and travel blogs. This has to be kept in mind when developing marketing strategies - and is seemingly being approached in the correct way by the national destination marketing organisation, SAT, when evaluating their domestic campaigns (NDT, 2011a; Rogerson \& Lisa, 2005).

The most important feature categories of the Park as a leisure destination were indicated as 'general features', followed by the 'natural features', 'infrastructural features' and lastly the 'availability of activities'. Some of these important features can directly be linked to the top constraints. Value for money is linked to the constraint of the Park being seen as too 
expensive. Importantly, financial constraints ('cannot afford it') was also indicated as the most prominent reason why the respondents had not yet been on holiday in general highlighting the aspect of affordability and value for money for this market. A second important factor is that of information. The majority of respondents who indicated uncertainty about the product offering and lack of information as constraints also indicated ease of finding information as very important to them.

The study indicates that providing value for money and ensuring affordability to the emerging black market is of extreme importance. The perceived time constraint is also an important aspect that needs to be addressed. Given that the majority of respondents indicated Kwa-Zulu Natal as their last destination visited (situated approximately 600km from the fieldwork location as opposed to the distance of $426 \mathrm{~km}$ to the Park), it seems that travelling far distances should not be a constraint as some of the respondents indicated. The emerging market needs to be educated on the ease of accessibility of the Park through existing transportation infrastructure and by distributing the product through the most appropriate channels as used by the market.

An increased level of awareness and interest in the wildlife and outdoor activities at the park could also eliminate additional constraints, making the Kruger National Park more appealing to the entire family. The emerging market could also be informed of the alternative activities and experiences available apart from wildlife.

The study is limited by a relatively small sample size, considering the size of the total population. No in-depth reasoning or probing questions could be asked with the selfadministered questionnaire to explore underlying and more personal reasoning of respondents. Future research could thus consider a qualitative approach such as focus groups. Further research could be done concerning the variations of the constraints and important factors across gender, age and income groups within the emerging domestic market. Importantly, future research should focus on incorporating knowledge related to constraint negotiation in leisure as discussed by various authors (such as Hung \& Petrick, 2012; Schneider \& Stanis, 2007; Son \& Yarnal, 2011) to inform these mentioned strategies that will assist in countering perceived constraints by facilitating the negotiation process (Hinch \& Higham, 2011). 


\section{Acknowledgements}

The authors wish to acknowledge the contributions of Ms. CM da Costa and Mrs. P Fani to the article.

\section{References}

Alipour, H, Kilic, H \& Zamani, N, 2013. The untapped potential of sustainable domestic tourism in Iran. Anatolia: An International Journal of Tourism and Hospitality Research, 24(3), 468-483.

Anil, G, Gupta, D.R \& Neelika, A, 2010. The relationship between perceived travel risk, travel safety, travel anxiety and intentions to travel: a path analysis study of domestic traveller in India. International Journal of Tourism and Travel, 3(1), 25-36.

Crawford, D \& Godbey, G, 1987. Reconceptualising barriers to family leisure. Journal of Leisure Sciences, 9:119-27.

Crawford, D, Jackson, E \& Godbey, G, 1991. A hierarchical model of leisure constraints. Journal of Leisure Sciences, 13:309-320.

DEAT, 1996. White paper on the Development and Promotion of Tourism in South Africa. http://scnc.ukzn.ac.za/doc/tourism/White_Paper.htm Accessed 7 June 2012.

Donaldson, R, Mehlomakhulu, T, Darkey, D, Dyssel, M \& Siyongwana, P, 2013. Relocation: to be or not to be a black diamond in a South African township? Habitat International, 39:114-118.

Du Plooy, G.M, 2009. Communication research - techniques, methods and applications. Juta, Cape Town.

Ferrario, F, 1988. Emerging leisure market among the South African black population. Journal of Tourism Management, 9(1), 23-38.

Flutter, M \& Wood, L, 1997. Domestic Tourism in South Africa (un)limited options?. Indicator South Africa, 14(2), 58-63.

Ghimire, K.B, 2013. The native tourist: mass tourism within developing countries. Earthscan Publications, Oxford.

Gilbert, D \& Hudson, S, 2000. Tourism demand constraints: a skiing participation. Annals of Tourism Research, 27(4), 906-925.

Godbey, G, Crawford, D.W \& Shen, X.S, 2010. Assessing hierarchical leisure constrants theory after two decades. Journal of Leisure Research, 42(1), 111-134. 
Goldberg, R.H \& Jansen van Rensburg, L.R, 2013. Relationships between ethnocentrism and lifestyle dimensions among a targeted consumer segment in Sandton. Journal of Contemporary Management, 10:362-383.

Grundlingh, A, 2006. Revisting the 'Old' South Africa: Excursions into South Africa's Tourist History under Apartheid, 1948-1990. South African Historical Journal, 56(1), 103-122.

Hampton, M.P \& Jeyacheya, J, 2014. Hot beaches, cool cities. Tourism and Economic Development in South-East Asia. Paper presented at a research seminar, International School of Thai Nguyen University, Vietnam. http://kar.kent.ac.uk/41741/ Accessed 18 July 2014.

Hinch, T \& Higham, J, 2011. Sport tourism development. 2nd edn. Channel View Publications, Toronto.

Hudson, H, 1999. Consumer behaviour in travel and tourism. Haworth Hospitality Press, Binghampton.

Hung, K \& Petrick, J.F, 2012. Testing the effect of congruity, travel constraints, and selfefficacy on travel intentions: an alternative decision-making model. Tourism Management, 33(4), 855-867.

Jackson, E, 1993. Recognising patterns of leisure constraints: results from alternative analyses. Journal of Leisure Research, 25:129-49.

Jackson, G, 1991. Leisure despite constraint: the impact of leisure constraints on leisure participation. Journal of Leisure Research, 23(4), 301-313.

Kim, S.S, Lee, C \& Klenosky, D.B, 2002. The influence of push and pull factors at Korean national parks. Journal of Tourism Management, 24(2), 169-180.

Koch, E \& Massyn, P, 2013. South Africa's domestic tourism sector: promises and problem. In Ghimire, KB (Ed.), The native tourist: mass tourism within developing countries. Earthscan Publications, Oxford.

Leibbrandt, M, Finn, A \& Woolard, I, 2012. Describing and decomposing post-apartheid income inequality in South Africa. Development Southern Africa, 29(1),19-34.

Mclntosh, R.W, Goeldner, C.R \& Ritchie, J.R, 1995. Tourism - principles, practices, philosophies. John Wiley, New York.

McQuire, F.A, 1984. A factor analytic study of leisure constraints in advanced adulthood. Journal of Leisure Sciences, 6(3), 313-326.

Mkhize, I.B, 1994. South African domestic tourism beyond apartheid. Development Southern Africa, 11(2), 249-252. 
Mutinda, R \& Mayaka, M, 2012. Application of destination choice model: factors influending domestic tourists destination choice among residents of Nairobi, Kenya. Tourism Management, 33(6), 1593-1597.

NDT, 2011a. Domestic tourism growth strategy 2012-2020. http://www.tourism.gov.za/AboutNDT/Branches1/domestic/Documents/Domestic\%2 OTourism\%20Growth\%20Strategy\%202012-\%2020 20.pdf Accessed 9 February 2012.

NDT, 2011b. National tourism sector strategy. http://www.tourism.gov.za/AboutNDT/ Publications/National\%20Tourism\%20Sector\%20Strategy\%20Executive\%20Summ ar.pdf Accessed 9 February 2012.

Nyaupane, G, Morais, D \& Graefe, A, 2004. Nature tourism constraints: a cross-activity comparison. Annals of Tourism Research, (31)3, 540-555.

Okello, M.M, Kenana, L \& Kieti, D, 2012. Factors influencing domestic tourism for urban and semiurban populations around Nairobi National Park, Kenya. Tourism Analysis, 17(1), 79-89.

Özel, H.C \& Kozak, N, 2012. Motive based segmentation of the cultural tourism market: a study of Turkish domestic tourists. Journal of Quality Assurance in Hospitality and Tourism, 13(3), 165-186.

Papatheodorou, A, Rosselló, J \& Xiao, H, 2010. Global economic crisis and tourism: consequences and perspectives. Journal of Travel Research, 49(1), 39.45.

Pearce, P.L, 2011. Tourist Behaviour and the Contemporary World. Channel View Publications, Ontario, Canada.

Pearce, P. L \& Lee, U, 2005. Developing the travel career approach to tourist motivation. Journal of Travel Research, 43(3), 226-237.

Pennington-Gray, L \& Kerstetter, D, 2002. Testing a constraints model within the context of nature-based tourism. Journal of Travel Research, (40):416.

Pennington-Gray, L, Thapa, B \& Hollard, S, 2002. Florida residents' constraints to parks and public lands visitation: an assessment of the validity of an intrapersonal, interpersonal and structural model. World Leisure Journal, 44(4), 51-60.

Rogerson, C, M \& Lisa, Z, 2005. 'Sho't left: Changing Domestic Tourism in South Africa. Urban Forum, 16(2), 88-111.

Rogerson, C.M, 2004. Regional tourism in South Africa: a case of 'mass tourism in the South'. GeoJournal, 60:229-237. 
Rule, S, Viljoen, J, Zama, S, Struwig, J, Langa, Z \& Bouare, O, 2003. Visiting friends and relatives (VFR): South Africa's most popular form of domestic tourism. Africa Insight, 33(1-2), 99-107.

Saayman, M, Saayman, A \& Rhodes, J.A, 2001. Domestic tourist spending and economic development: the case of North West Province. Development Southern Africa, 18:443-455.

SANParks, 2012. Kruger National Park. http://www.sanparks.co.za/parks/kruger/ Accessed 11 April 2012.

SANParks, 2013. SANParks Annual Report 2012/2013. http://www.sanparks.co.za/ assets/docs/general/annual-report-2013.pdf Accessed 18 July 2014.

SAT, 2010. The marketing tourism growth strategy for South Africa 2011 - 2013. South African Tourism, Johannesburg. www.southafrica.net Accessed 5 February 2014.

SAT, 2013. South African Tourism domestic indicators: July to September 2013. South African Tourism, Johannesburg. www.southafrica.net Accessed 6 March 2014.

Schneider, I.E \& Stanis, S.A.W, 2007. Coping: an alternative conceptualization for constraint negotiation and accommodation. Leisure Studies, 29, 391-401.

Schneider, I.E, Schroeder, S.L \& Schwaller, A, 2011. Structural constraints to wilderness. International Journal of Wilderness, 17(1), 14-21.

Sindiga, I, 1996. Domestic tourism in Kenya. Annals of Tourism Research, 23(1), 19-31.

Singh, S \& Krakover, S, 2015. Tourist experience at home - Israeli domestic tourism. Tourism Management, 46, 59-61.

Smeral, E, 2010. Impacts of the world recession and economic crisis on tourism: forecasts and potential risks. Journal of Travel Research, 49(1), 31-38.

Son, J.S \& Yarnal, C.M, 2011. An integration of constraints and benefits within an older women's social club: an examination, extension and critique. Leisure Sciences: An Interdisciplinary Journal, 33(3), 205-227.

StatsSA, 2012. Press statement: income and media expenditure survey (IES) 2010/2011, Statistics South Africa, Pretoria.

Sun, X.X, Chi, G.Q.C \& Xu, H.G, 2013. Developing destination loyalty: the case of Hainan Island. Annals of Tourism Research, 43, 547-577.

Teigland, J, 2000. The effects on travel and tourism demand from three mega-trends. CABI Publishing, Wallingford.

Thapa, B, 2012. Why did they not visit? Examining structural constraints to visit Kafue National Park, Zambia. Journal of Ecotourism, 11(1), 74-83. 
Tregenna, F \& Tsela, M, 2012. Inequality in South Africa: the distribution of income, expenditure and earnings. Development Southern Africa, 29(1), 35-61.

Van der Merwe, P \& Saayman, M, 2008. Travel motivation of visitors to the Kruger National Park. Koedoe, 50(1),154-159.

Visagie, J \& Posel, D, 2013. A reconsideration of what and who is middle class in South Africa. Development Southern Africa, 30(2), 149-167.

Visser, G, 2004. Second homes and local development: issues arising from Cape Town's De Waterkant. GeoJournal, 60:259-271.

Wight, $P, 2002$. Supporting the principles of sustainable development in tourism and ecotourism: government's potential role. Current Issues in Tourism, 5:222-243.

World Bank, 2007. Zambia economic and poverty impact of nature based tourism. http://www.aec.msu.edu/fs2/zambia/resources/433730ESW0P09610Box334066B0 1PUBLIC1.pdf Accessed 11 April 2012.

WTTC, 2013. Travel and tourism economic impact 2013 - world. WTTC, London. http://www.wttc.org/site_media/uploads/downloads/world2013_1.pdf Accessed 28 April 2014.

Yang, Y, Liu, Z.H \& Qi, Q, 2014. Domestic tourism demand of urban and rural desinations in China: does relative income matter? Tourism Management, 40, 193-202. 